\title{
Living skins: environmental benefits of green envelopes in the city context
}

\author{
D. Roehr ${ }^{1} \&$ J. Laurenz ${ }^{2}$ \\ ${ }^{1}$ Greenskins_Lab, Design Centre for Sustainability [DCS], \\ School of Architecture and Landscape Architecture [SALA], \\ University of British Columbia, Canada \\ ${ }^{2}$ Greenskins_Lab, DCS - SALA, University of British Columbia, Canada
}

\begin{abstract}
This research reports the potential environmental benefits derived from an overall intervention of living skins [green roofs and green façades] in the city core of Vancouver, Canada. These include the reduction in cooling and heating demand; reduction in stormwater runoff; improvement of air quality; enrichment of urban biodiversity and urban agriculture; reduction in the urban heat island effect; the contribution to carbon neutral architecture; and an assessment of different construction systems. It analyses the environmental behaviour of the selected site by applying the Seattle Green Factor.

The research focuses on the energy performance of a typical residential building within the selected area, through the Energy 10 simulation program. It also analyses the reduction in stormwater runoff through the Curve Number Method; as well as the reduction of $\mathrm{CO}_{2}$ emissions based on related research.

Obtained data shows that the total energy used for cooling is reduced [100\%] through the greening of roofs and façades, which means the $9 \%$ of the total energy demand by the studied building. It also shows that $\mathrm{CO}_{2}$ emissions would decrease by $9 \%$; and stormwater runoff would be reduced by $4 \%$. The research compares these findings with previous related research on green roofs, façades and urban forests. Its findings suggest that these types of "living skins" interventions achieve better environmental performance in warm-dry climates where cooling energy demand is greater.
\end{abstract}

Keywords: living skins, green roofs, green façades, green walls, energy simulation, energy savings, $\mathrm{CO}_{2}$ emissions, stormwater runoff, living skins technology, environmental benefits. 


\section{Introduction}

Many attempts are currently being made in order to create greener urban environments. It is important to mention a set of initiatives, implemented in policies, which have been carried out through the so-called "green factors". It started in Berlin and Hamburg, Germany during the 1990s with the Biotope Area Factor (BAF [1]). Similarly, the Greenspace Factor was recently implemented (2001) in an urban development in Malmö, Sweden (Greenspace Factor [2]). Even more recently, in 2007, the City of Seattle developed its Green Factor (Green Factor [3]). Green factors promote increased green surfaces in cities and their main objectives could be summarized as follows:

- Safeguarding and improving microclimatic and atmospheric hygiene

- Safeguarding and developing soil function and water balance

- Creating and enhancing the quality of plant and animal habitats

- Improving the urban environment, reducing energy demand and $\mathrm{CO}_{2}$ emissions
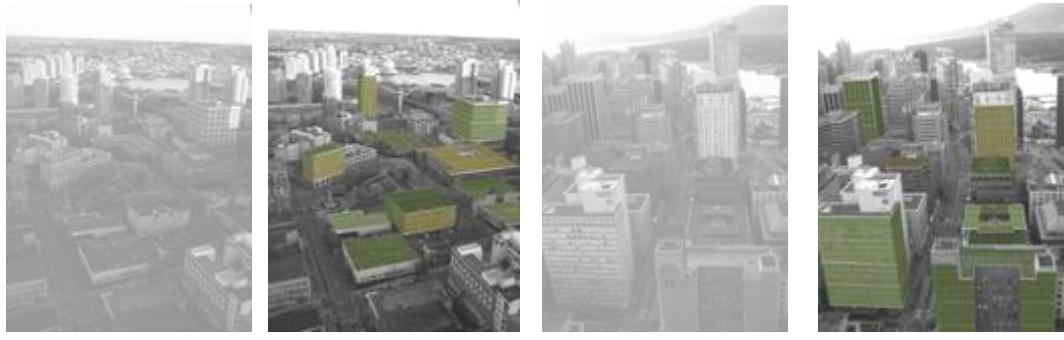

Figure 1: Overall green surfaces intervention [green façades + green roofs].

But do these green interventions make sense? Are they worth it? Under what terms are these environmental benefits achieved? This research attempts to bring clarity on the suitability of such green interventions. It analyses the degree to which these environmental goals are achieved by greening a selected percentage of urban surfaces like green roofs and green facades within downtown Vancouver. It studies the expectations that such a "living skins" intervention would provide, focused on the contribution to reduce energy demand by buildings, $\mathrm{CO}_{2}$ emissions, and stormwater runoff. To achieve this, it selects a specific site in the core of downtown Vancouver, and analyses existing green and grey surfaces. It then applies the Seattle Green Factor which requires an increase in green surfaces by $30 \%$ on flat roof areas, $30 \%$ of sidewalk areas, and $15 \%$ on façade areas in order to achieve the 0.3 value suggested by the Factor. The research also analyses existing living façade technologies, categorizing them by opaque or transparent green façades. It proposes different systems for different orientations in order to achieve maximum energy performance.

The research argues that obtained results - a $9 \%$ reduction in energy demand and $\mathrm{CO}_{2}$ emissions and a $4 \%$ reduction in stormwater runoff - are lower in comparison with other related research. It questions the Energy 10 computer program used, explaining the difficulties and proposes to introduce some characteristics of living materials such as seasonal changing properties, material 
absortance and evapotranspiration. The research, based on similar studies, suggests better environmental performance would be achieved by a proposed living skins intervention. But this is difficult to show through existing energy simulation programs, due to their limitations for introducing living materials. However, it also acknowledges that these types of green interventions would contribute more to identified environmental benefits in warm-dry climates.

According to the modest results obtained in this research, it questions the suitability of such green interventions, considering the efforts that need to be established to make them real and the benefits achieved by doing so. However, it also admits that other similar research studies obtained higher environmental benefits. Moreover there are additional environmental benefits such as the influence that these living skins interventions would have on food production and urban biodiversity, which could be crucial factors in properly justifying these types of living skins interventions.

\section{Methodology}

In the first phase the case study site is selected within downtown Vancouver. The area selected is due to the paper's interest in analysing a dense urban area which combines residential and commercial buildings. It is a neighbourhood from the 1960s, in which new high rise buildings are still developing, increasing its density as promoted through the "EcoDensity" initiative (City of Vancouver [4]) launched by the City of Vancouver.

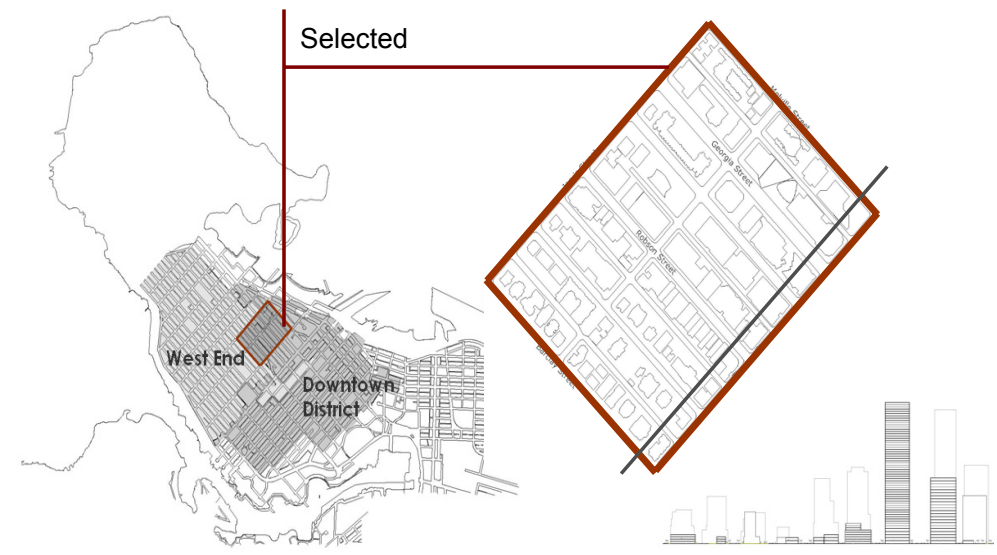

Figure 2: The selected site in downtown Vancouver. It combines the residential neighbourhood - west end - and downtown district neighbourhood.

The research analyses existing conditions of the site, in terms of land use; green versus grey surfaces; current energy consumption by buildings based on their usage; and $\mathrm{CO}_{2}$ emissions depending on the energy source; it also calculates current flat roof and building façade areas. 


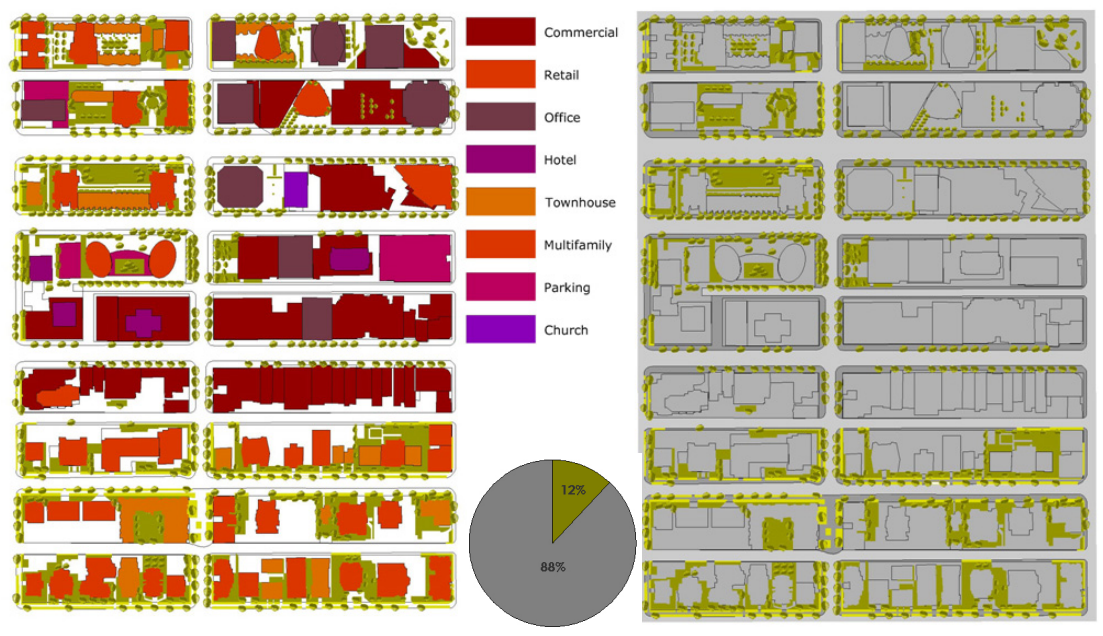

Figure 3: $\quad$ Land use and grey vs. green surfaces analysis of the selected site.

Table 1: $\quad$ Characteristics of the selected site.

\begin{tabular}{|c|c|c|c|c|c|}
\hline \multicolumn{2}{|l|}{ LAND USE } & \multicolumn{2}{|c|}{ GREEN vs. GREY } & \multicolumn{2}{|l|}{ ENERGY - $\mathrm{CO}_{2}$} \\
\hline & Area [ha] & & Area [ha] & Energy [MJ/year]* & $\mathrm{CO}_{2}[\mathrm{Tn}]^{* *}$ \\
\hline $\begin{array}{r}\text { Commercial } \\
\text { Retail } \\
\text { Office } \\
\text { Hotel } \\
\text { Church } \\
\text { Parking }\end{array}$ & 28ha & $\begin{array}{l}\text { Green } \\
\\
\end{array}$ & $\begin{array}{l}\text { 2,3ha } \\
{[12 \%]}\end{array}$ & $\begin{array}{l}327 \mathrm{MJ} / \text { year } \\
{[235 \mathrm{MJ}-\text { gas }} \\
92 \mathrm{MJ} \text {-electr] }\end{array}$ & $\begin{array}{l}13425 \mathrm{Tn} \\
\text { [12402Tn-gas } \\
1022 \mathrm{Tn} \text {-elec] }\end{array}$ \\
\hline $\begin{array}{l}\text { Residential } \\
\text { Townhouse } \\
\text { Multi-family }\end{array}$ & 40ha & Grey & $\begin{array}{l}\text { 17,2ha } \\
{[88 \%]}\end{array}$ & $\begin{array}{l}185 \mathrm{MJ} / \text { year } \\
{[133 \mathrm{MJ} \text {-gas }} \\
52 \mathrm{MJ} \text {-electr] }\end{array}$ & $\begin{array}{l}7586 \mathrm{Tn} \\
\text { [7019Tn-gas } \\
\text { 566Tn-elec] }\end{array}$ \\
\hline $\begin{array}{l}\text { People } \\
{[8.500]}\end{array}$ & & & & & \\
\hline
\end{tabular}

*The energy estimate is based on energy targets for the South East False Creek Development in downtown Vancouver (City of Vancouver [5]).

** $\mathrm{CO}_{2}$ emissions estimate assumes $1 \mathrm{~kg} / 1 \mathrm{kwh}$ gas emits $190 \mathrm{gCO}_{2}$, and $1 \mathrm{kwh}$ electricity emits $40 \mathrm{gCO}_{2}$ (Environmental Food and Rural Affairs-UK [6]).

The research applies the Seattle Green Factor [3] to the case study area. In order to achieve the 0.3 value suggested by the Factor, it proposes to green $30 \%$ of existing flat roofed areas, $30 \%$ of existing sidewalk areas and $15 \%$ of existing building façade areas. By doing so, existing green surface areas increase from $12 \%$ to $28 \%$ (Figure 4 ). 

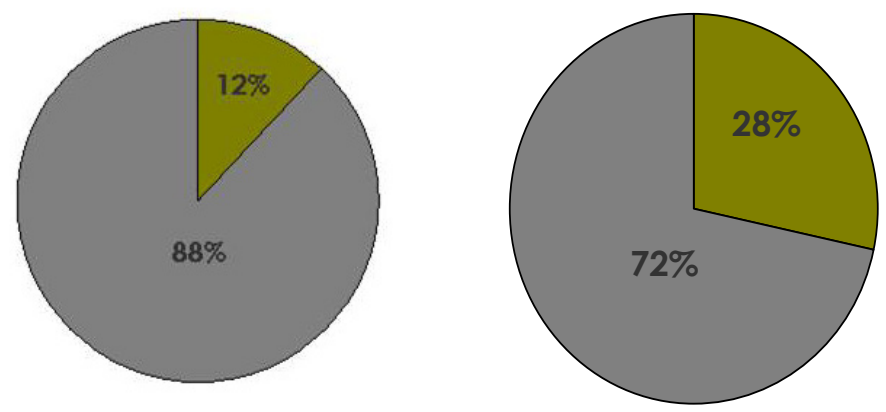

Figure 4: Grey vs. green surfaces, before and after the proposed green intervention.

\section{Energy performance}

The research studies in depth environmental benefits derived from saving the energy demand by buildings. In analysing the energy performance of residential buildings of the selected site, the research defines a typical residential building after studying existing residential buildings. The following table summarizes the characteristics of this building.

Table 2: $\quad$ Characteristics of the typical residential building.

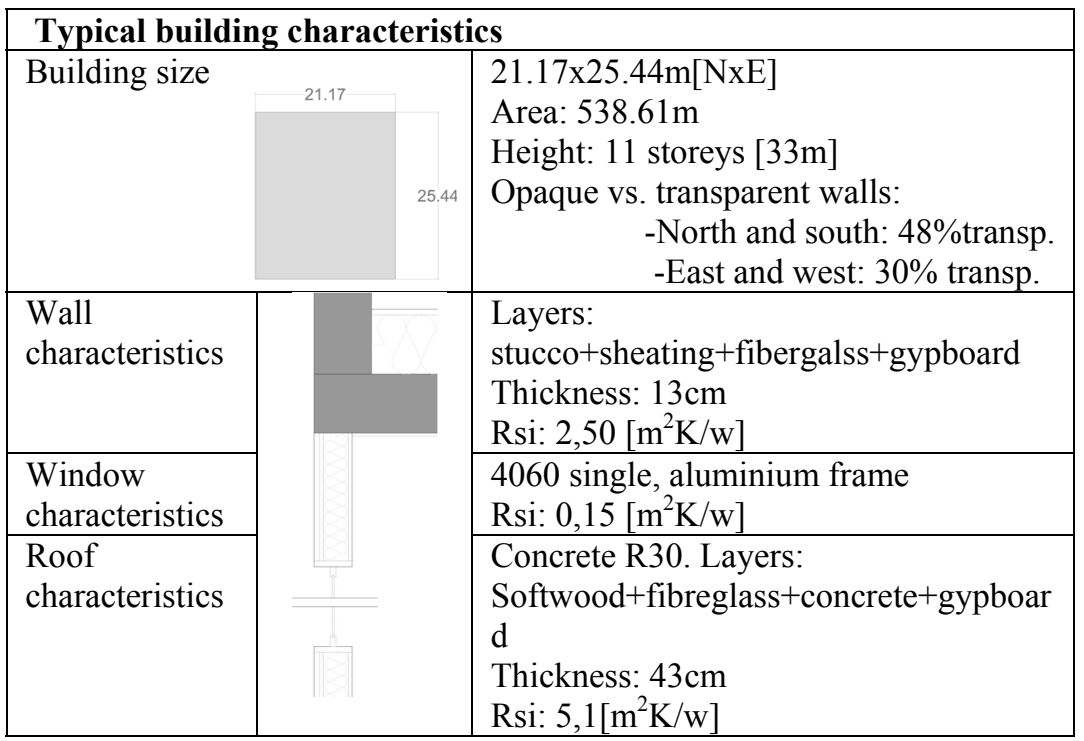

The research suggests achieving the Seattle Green Factor by greening roofs and façades. By incorporating these living skins, the new "living building "would be composed of the materials summarized in the following Table 3. 
Table 3: $\quad$ Characteristics of the living skins building.

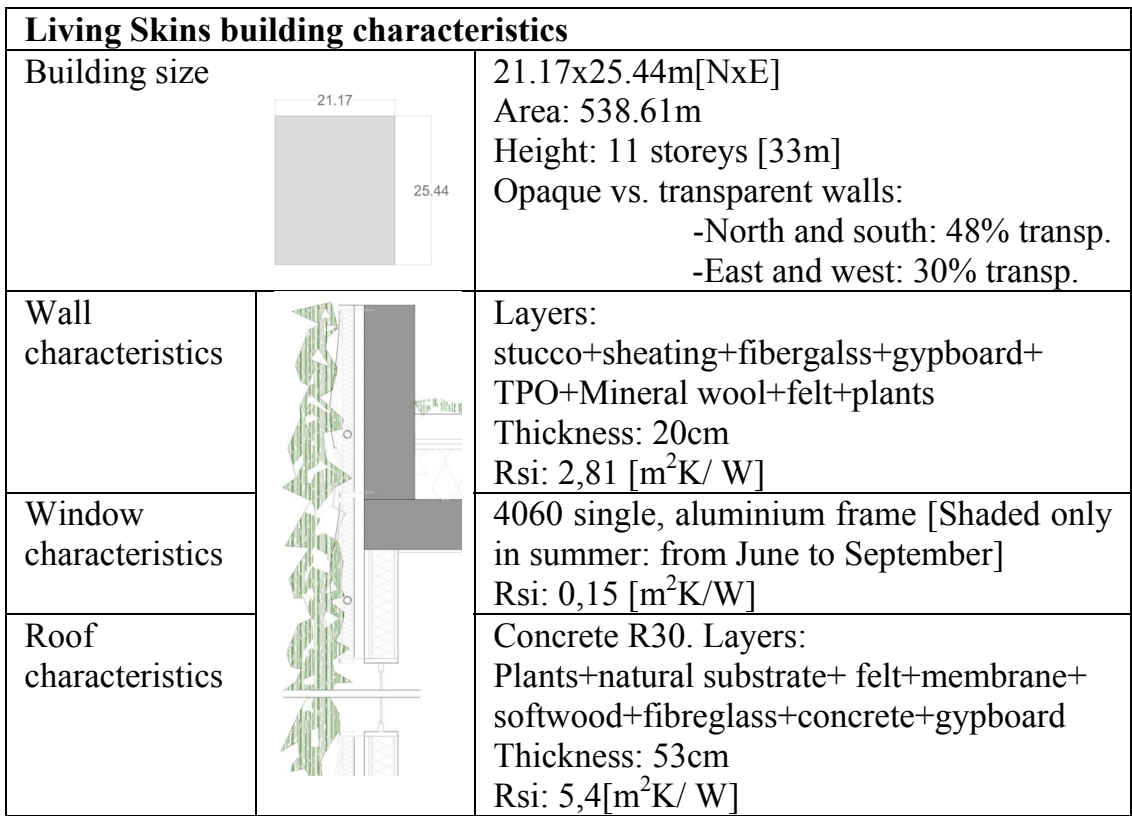

Introducing the characteristics of the buildings specified above into the Energy 10 simulation program, the paper achieved the following results:

Table 4: Data obtained after simulating the energy performance of the living skins building versus the typical building, through the Energy 10 program.

\begin{tabular}{|c|c|c|c|c|}
\hline \multicolumn{3}{|c|}{ LIVING SKINS BUILDING } & \multirow{2}{*}{\multicolumn{2}{|c|}{ ENERGY10 }} \\
\hline & & & & \\
\hline & & & Cooling & Heating \\
\hline \multirow[t]{2}{*}{ PEAK LOAD } & Month/Hour & & 2-AUG 15PM & 28-JAN-9AM \\
\hline & Total Load & $\mathrm{kW}$ & 70,92 & $-202,79$ \\
\hline \multirow{26}{*}{$\begin{array}{l}\text { LOADS/DEMANDS } \\
\text { MOUNTHLY }\end{array}$} & JANUARY & & & \\
\hline & Demand & MWh & & $-137,731$ \\
\hline & \begin{tabular}{|l|} 
FEBRUARY \\
\end{tabular} & & & \\
\hline & Demand & MWh & & $-95,65$ \\
\hline & \begin{tabular}{|l|} 
MARCH \\
\end{tabular} & & & \\
\hline & Demand & MWh & & $-76,59$ \\
\hline & \begin{tabular}{|l|} 
APRIL \\
\end{tabular} & & & \\
\hline & \begin{tabular}{|l|} 
Demand \\
\end{tabular} & MWh & & $-39,50$ \\
\hline & MAY & & & \\
\hline & Demand & MWh & & $-4,64$ \\
\hline & \begin{tabular}{|l|} 
JUNE \\
\end{tabular} & & & \\
\hline & Demand & MWh & & $-12,51$ \\
\hline & \begin{tabular}{|l|} 
JULY \\
\end{tabular} & & & \\
\hline & Demand & MWh & & $-0,05$ \\
\hline & \begin{tabular}{|l|} 
AUGUST \\
\end{tabular} & & & \\
\hline & \begin{tabular}{|l|} 
Demand \\
\end{tabular} & MWh & & $-1,76$ \\
\hline & \begin{tabular}{|l|} 
SEPTEMBER \\
\end{tabular} & & & \\
\hline & \begin{tabular}{|l|} 
Demand \\
\end{tabular} & MWh & & $-24,66$ \\
\hline & \begin{tabular}{|l|} 
OCTOBER \\
\end{tabular} & & & \\
\hline & \begin{tabular}{r|} 
Demand \\
\end{tabular} & MWh & & $-47,25$ \\
\hline & \begin{tabular}{|l|} 
NOVEMBER \\
\end{tabular} & & & \\
\hline & Demand & $\mathrm{MWh}$ & & $-101,78$ \\
\hline & \begin{tabular}{|l|} 
DECEMBER \\
\end{tabular} & & & \\
\hline & \begin{tabular}{|l|} 
Demand \\
\end{tabular} & MWh & & $-135,13$ \\
\hline & \begin{tabular}{|l|} 
ANNUAL \\
\end{tabular} & & & \\
\hline & \begin{tabular}{|l|} 
Demand \\
\end{tabular} & MWh & 0,00 & $-677,24$ \\
\hline
\end{tabular}

\begin{tabular}{|c|c|c|c|c|}
\hline \multicolumn{3}{|c|}{ TYPICAL BUILDING } & \multirow{2}{*}{\multicolumn{2}{|c|}{ ENERGY10 }} \\
\hline & & & & \\
\hline & & & Cooling & Heating \\
\hline \multirow[t]{2}{*}{ PEAK LOAD } & Month/Hour & & 2-AUG 17PM & 28-JAN-9AM \\
\hline & Total Load & $\mathrm{kW}$ & 150,04 & $-204,55$ \\
\hline \multirow{26}{*}{$\begin{array}{l}\text { LOADS/DEMAN } \\
\text { MOUNTHLY }\end{array}$} & JANUARY & & & \\
\hline & \begin{tabular}{|l|} 
Demand \\
\end{tabular} & MWh & & $-139,134$ \\
\hline & \begin{tabular}{|l|} 
FEBRUARY \\
\end{tabular} & & & \\
\hline & \begin{tabular}{|r|} 
Demand \\
\end{tabular} & MWh & & $-96,85$ \\
\hline & \begin{tabular}{|l|} 
MARCH \\
\end{tabular} & & & \\
\hline & \begin{tabular}{|l} 
Demand \\
\end{tabular} & MWh & & $-77,81$ \\
\hline & \begin{tabular}{|l|} 
APRIL \\
\end{tabular} & & & \\
\hline & \begin{tabular}{|l} 
Demand \\
\end{tabular} & MWh & & $-40,45$ \\
\hline & MAY & & & \\
\hline & Demand & MWh & & $-5,34$ \\
\hline & JUNE & & & \\
\hline & Demand & MWh & 20,2 & \\
\hline & \begin{tabular}{|l|} 
JULY \\
\end{tabular} & & & \\
\hline & Demand & MWh & 40,02 & \\
\hline & AUGUST & & & \\
\hline & Demand & MWh & 39,33 & \\
\hline & \begin{tabular}{|l|} 
SEPTEMBER \\
\end{tabular} & & & \\
\hline & Demand & MWh & 0,71 & \\
\hline & \begin{tabular}{|l|} 
OCTOBER \\
\end{tabular} & & & \\
\hline & \begin{tabular}{|l|} 
Demand \\
\end{tabular} & MWh & & $-48,16$ \\
\hline & \begin{tabular}{|l|} 
NOVEMBER \\
\end{tabular} & & & \\
\hline & Demand & MWh & & $-102,96$ \\
\hline & \begin{tabular}{|l|} 
DECEMBER \\
\end{tabular} & & & \\
\hline & \begin{tabular}{|l|} 
Demand \\
\end{tabular} & MWh & & $-136,50$ \\
\hline & ANNUAL & & & \\
\hline & \begin{tabular}{|l} 
Demand \\
\end{tabular} & MWh & 100,26 & $-647,20$ \\
\hline
\end{tabular}


Results show that while a typical residential building of the selected area demands 100,26MWh for cooling, the living skins building would not demand energy for cooling. This means a 100\% reduction in cooling would be achieved. Considering the total energy demand by the typical building [747,46 MWh], the reduction achieved by incorporating living skins would be $9 \%$ [70,2MWh]. This also means that $\mathrm{CO}_{2}$ emissions produced to generate this energy would be reduced by $9 \%$. Moreover, in terms of the capacity of plants to trap air pollutants such as $\mathrm{CO}_{2}$; grassy plants (on lawns) would trap $4.38 \mathrm{~kg} / \mathrm{m}^{2}$ per year; shrubby plants (on green roofs) would trap $8.76 \mathrm{~kg} / \mathrm{m}^{2}$; and climber plants (on green walls) would trap $6.57 \mathrm{~kg} / \mathrm{m}^{2}$ (Schaefer [7]).

The research compares these findings with related research having similar analysis. Given this, according to research studies on green roofs, the energy required for space conditioning due to the heat flow through the green roof, would be reduced by more than $75 \%$ (Liu and Baskaran [8]). In addition, green walls contribute significantly to the reduction of indoor air temperature in the summer, by reducing the external air temperature of a west-facing orientation up to $4^{\circ} \mathrm{C}$ on a clear August day in Japan; (Hoyano [9]) and by $5^{\circ} \mathrm{C}$, in South Africa (Holm [10]). This cooling effect of plants could reduce the annual cooling energy use by $31 \%$, and windbreak plantings around unprotected homes would reduce annual heating energy use by $15 \%$ (McPherson et. al. [11]). According to computer simulations, in a warm climate such as Madrid, cooling energy use reduction could reach up to $45 \%$ and heating reduction up to $23 \%$ (Laurenz [12]).

Table 5: $\quad$ Energy behaviour of opaque and transparent living façades.

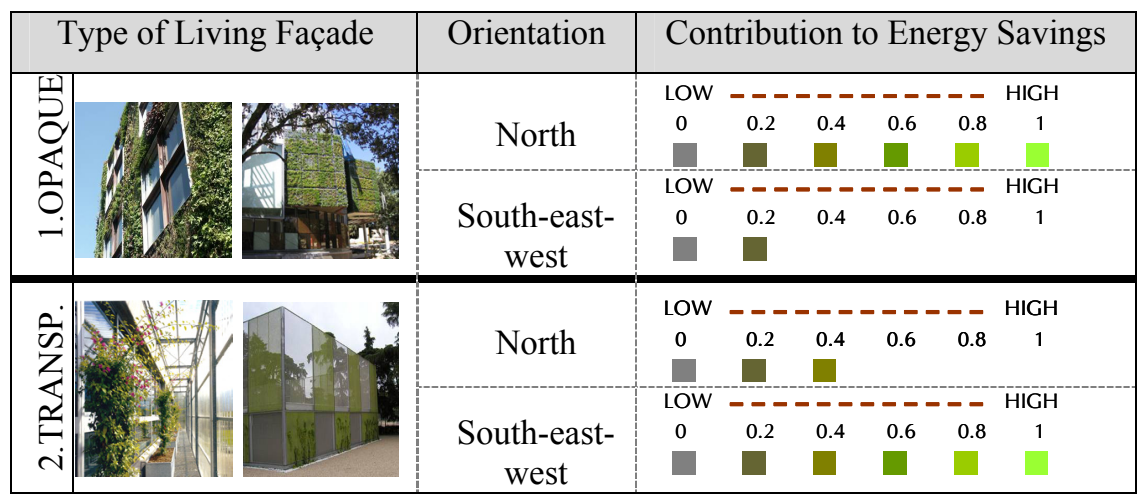

There are two main reasons why results achieved in this research are relatively lower than those achieved in related studies. First is the climate. Many of the analysed research studies are based in warm-dry or hot-arid climates. Second are the difficulties to introduce the characteristics of living skins into an energy simulation program. When simulating a living material it is not possible to introduce seasonal characteristics that change over time, seasonally, as with plants do. Moreover, there are some aspects of these living materials such as the 
absortance, photosynthesis, evapotranspiration properties, etc. which could not be introduced as input into the Energy 10 simulation program. This suggests, so far, that it is better to analyse living skins materials - living roofs and living walls - through using test rooms.

The research also analyses existing living façade technologies in terms of their energy performance. It identifies these technologies in two main categories: opaque green façades and transparent green façades. It suggests that opaque green façades perform better for a northern orientation, due to its higher insulation capacity; while transparent green façades perform better for all other orientations, especially western. This is mainly due to the natural condition of deciduous plants which would cover a transparent façade in the summer, and therefore refresh it; yet would allow the solar energy to enter into the building in the winter, when the plant is bare (Table 5).

\section{Stormwater runoff}

The research calculates the contribution of proposed new living skins to reduce stormwater run-off, based on the CN (Curve Number) method (US-NRCS). With the Curve Numbers of each cover type (roof, street, and green open space like parks and lawns); and the daily rainfall data for Vancouver (Environment Canada [13]), the runoff rate created from each cover type has been calculated. The calculation uses an average $\mathrm{CN}$ of 69 for the soil texture (silt loam or loam) with a moderate rate of water transmission $(0.15-0.30 \mathrm{in} / \mathrm{hr})$ (Cronshey et al. [14]). As recent research shows that compacted urban soil can influence infiltration, the $\mathrm{CN}$ of 69 also assumes that the soil is hand-compacted (Pitt 2002 [15]). In order to achieve a contribution of green roofs towards reducing runoff, this paper uses the updated Crop Coefficient Method (California Department of Water Resources, 2000 [16]), where the runoff reduction rate of a green roof is equivalent to the evapotranspiration rate. By combining this rate and the green roofs areas, the total runoff reduction of green roofs is achieved.

In doing so, the results of such a living skins intervention shows that by greening $30 \%$ of existing flat roofed areas, and $30 \%$ of existing sidewalk areas, stormwater runoff would be reduced by $4 \%$.

\section{Conclusion/Discussion}

This research shows the potential of living skins interventions. It provides data on energy savings and a reduction of $\mathrm{CO}_{2}$ emissions, as well as the influence on stormwater runoff. Results demonstrate that by greening a certain area of a city, in order to achieve the requirements indicated in the Seattle Green Factor, the energy demand by buildings would be reduced by $9 \%$ [including a $100 \%$ reduction for cooling]. This means that the $\mathrm{CO}_{2}$ emitted to generate this energy would also be reduced [by $9 \%$ ]. It also shows runoff would be reduced by $4 \%$.

However, the research highlights the difficulties found in introducing living materials into energy simulation computer programs, in this case into Energy 10. This is mainly due to the impossibility of introducing changing properties of 
materials. While living skins change their characteristics over time, the Energy 10 simulation program only accepts input with invariable properties overtime. Moreover, there are some crucial characteristics of living materials that could not be introduced such as the evapotranspiration, photosynthesis, absortance, etc. All in all, this suggests it is better to analyse the performance of living materials in testing rooms, with physical living roofs and façades tested with computerized sensor equipment.

In order to achieve better energy performance in existing living wall technologies, the research categorizes them into opaque green façades and transparent green façades. It concludes that opaque green façades would perform better for northern orientations, while transparent green façades perform better with the others, especially western orientation.

Comparing findings obtained by the energy simulation program with other related research - on green roofs, walls and urban forests - it shows how results achieved in this research are significantly more modest than those analysed in other studies. This is mainly due to the different climatic conditions that different researches studied, as well as given that this paper is based on simulation programs while other research is mainly based on real data achieved from test rooms. However, the research concludes that proposed living skins intervention would achieve better energy performance in warm-dry climates. (In Madrid the total energy saving would be close to $30 \%$ (Laurenz [12]), while according to this research the total energy savings in Vancouver would be close to $9 \%$ ).

More research studies should be focused on analysing the energy performance of living skins, through test rooms, in order to achieve more accurate data. The research also suggests there are many other environmental aspects of living skins which have been scarcely analysed. This includes; the contribution to enrich urban biodiversity, to food production through urban agriculture; the contribution to carbon neutral architecture; a cost and benefits assessment; among others. This would be crucial to definitely answer the suitability of such living skins interventions.

\section{References}

[1] Biotope Area Factor (BAF), 1994, Berlin, Germany. http://www.stadtentwicklung.berlin.de/umwelt/landschaftsplanung/bff/inde X_en.shtml

[2] Greenspace Factor, 2001, Malmö, Sweden. http://www.map21ltd.com /scan-green/bo01.htm

[3] Green Factor, 2007, Seattle, US. http://www.seattle.gov/dpd/Permits/ GreenFactor/

[4] City of Vancouver. Eco-Density initiative, 2006, Vancouver, Canada. http://www.vancouver-ecodensity.ca/

[5] City of Vancouver. Sustainability Indicators, Targets, Stewardship \& Monitoring for South East False Creek. http://www.city.vancouver.bc.ca/ ctyclerk/cclerk/20050301/ph2.htm. pp. 5, 2005. 
[6] Department for environmental food and rural affairs - UK. Accessed April 2007 from http://www.defra.gov.uk/, 2007.

[7] Schaefer, Rudd, Vala. 2004. "Urban Biodiversity". Captus Press, Ontario, 2004.

[8] Liu, K., and Baskaran, B. 2003. "Thermal Performance of Green Roofs Through Field Evaluation”. North American Green Roof Infrastructure Conference. May 29-30, 2003; Chicago, Illinois.

[9] Hoyano, A. 1988. "Climatological Uses of Plants for Solar Control and the Effects on the Thermal Environment of a Building". Ed. Energy and Buildings. Vol 11, \#1-3, pp. 181-199. Tokyo 1988.

[10] D. Holm. 1989. "Thermal Improvement by means of Leaf Cover on External Walls - A Simulation Model”. Ed. Energy and Buildings. Vol 14, pp. 19-30. South Africa. 1989.

[11] McPherson, E. G., Nowak, D. J., et. al. 1993. “Chicago's Evolving Urban Forest: Initial report of the Chicago Urban Forest Climate Project". North-eastern Forest Experiment Station, pp 40-41. Radnor, Pennsylvania, 1993.

[12] Laurenz, J. 2005. “Natural Envelope: The green element as a boundary limit". The 2005 World Sustainable Building Conference. Tokyo, 2005.

[13] Environment Canada, 2006. http://www.climate. weatheroffice.ec.gc.ca/ Welcome_e.html

[14] Cronshey, R.G., Roberts, R.T., and Miller, N., 1986. "Urban Hydrology for Small Watersheds" (TR-55 Revised). Washington, D.C.

[15] Pitt, R., Chen, S.E., and Clark., S. 2002, "Compacted Urban Soils: Effects on Infiltration and Bioretention Stormwater Control Designs". The 9th International Conference on Urban Drainage. IAHR, IWA, EWRI, and ASCE. Portland, Oregon, September 8-13, 2002.

[16] California Department of Water Resources, 2000. "A Guide to Estimating Irrigation Water Needs of Landscape Plantings in California". Department of Water Resources Bulletins and Reports, 2000. 